Agricultural Journal 5(3): 151-156, 2010

ISSN: $1816-9155$

(C) Medwell Journals, 2010

\title{
Determinants of Food Insecurity among Arable Farmers in Edo State, Nigeria
}

\author{
O. Ojogho \\ Department of Agricultural Economics, University of Benin, Edo State, Nigeria
}

\begin{abstract}
The examined the determinants of food insecurity among arable farmers in Egor and Oredo local government areas of Edo state in Nigeria. Both secondary and primary data were used. The descriptive statistics used the Greer-Thorbecke distributional measure of food insecurity while the inferential statistics used a multiple binomial logit regression model to analyze data of a set of socio-economic variables as the explanatory variables and food insecurity status as independent variable. The result showed that 41-50 years age group had $13.10,2.90$ and $0.86 \%$ as headcount index, short fall index and severity of food insecurity while the households with male as head had $21.62,5.62$ and $1.91 \%$ as headcount index, short fall index and severity of food insecurity, respectively. The education level of farmers, house hold size, output level of house hold and per capita income of the house hold were found to significantly affect food insecurity in the area. The probability of a house hold being food insecure due to house hold size, house hold dependency ratio, sex of house hold head, age and the level of education were $0.867,0.815,0.476,0.812$ and 0.018 , respectively. At the mean values of determinants of food insecurity in the study the probability of a house hold being food insecure was $0.997(99.7 \%)$. Approximately, three in every four people were found to be food insecure. Effort should be made to improve the income earning capacity of the house holds, their education levels and reduce the house hold size with a view to reducing their dependency ratio.
\end{abstract}

Key words: Short-fall, severity, food, hunger, food insecurity, probability of food insecurity

\section{INTRODUCTION}

The rate of increase in undernourishment in Africa vastly exceeds that of other developing regions of the world. In Africa, millions hover near starvation in a world of plenty. Since 1990, food availability per capita in SubSaharan Africa has declined by 3\%. This compares to per capita increases of $>30 \%$ in Asia and $20 \%$ in Latin America. The United Nations Food and Agriculture Organization (FAO, 2002) has estimated that almost 200 million Africans were undernourished at the dawn of the millennium compared with 133 million 20 years earlier. Yet West Africa has gone against the trend in the rest of Africa with its numbers and the prevalence of undernourishment falling dramatically over the period and this is the reason for optimism that trends can be reversed in other parts of Africa.

Countries that stand out are Benin, Ghana and Nigeria but they were the only Sub-Saharan African countries that had consistent decline in both the numbers and the prevalence of undernourished people over the past 20 years. About 33\% of people in Sub-Saharan Africa are undernourished, compared to about $6 \%$ in North Africa and $15 \%$ in Asia. About $>60 \%$ of the undernourished are in Eastern Africa with more than half of the populations in Congo Democratic Republic and Mozambique affected, while Angola, Cameroon, Ethiopia, Kenya, Tanzania and
Zambia show prevalence rates between 40 and 50\%. Nigeria's prevalence rate is low but its large population means that the country accounts for $22 \%$ of the food insecure in West and Central Africa. Achieving food security is imperative but how to do so is an elusive, complex problem. Part of the problem is the very low current and past levels of investment in productivity increasing measures in African agriculture which have meant high unit costs of production and progressive environmental degradation.

The results are low incomes for farmers and other rural residents, reduced competitiveness and increasing food insecurity and child malnutrition. Nigeria is no exception. Nigeria's quest for food security and sustainable agricultural development will need to be addressed along related factors if Nigeria is to meet with the millennium development goals. According to Abalu, about 14 million or $16 \%$ of the Nigeria population were food insecure (Abulu, 1990). This means that these people were either unable to consume enough food to allow for active working life and attain energy from their diets to prevent serious health risks or stunted growth. However, this has increased over the years. Nigeria, with an arable land area of 71.2 million ha but with $<34$ million ha under cultivation $(\mathrm{FAO}, 2005)$ is among the countries in Sub-Sahara Africa experiencing significant food shortages as over $40 \%$ of the country's population is estimated to be critically food 
insecure (Idachaba, 2004). Studies indicate that the socioeconomic characteristics of a household and resources available for production exert enormous influence on the nutritional status of a household (Olayemi, 1998; Rasaki et al., 2006). Generally, whatever is consumed to provide energy and nourishment for the human body for an active and healthy life is term food (Okolo, 2004). Food is a basic human need and the major source of nutrients needed for human existence. Common staples in most Nigerian homes are insufficient and do not provide a balanced diet as such, malnutrition is prevalent in most homes and their ability to utilise food to their maximum benefit is hampered and the productivity of most households is reduced. They are therefore closely identified with poverty and food insufficiency. Food security indicates the availability of and access to food. The issue, according to Ayalew (1997) became prominent in the $1970 \mathrm{~s}$ and has been a topic of considerable attention since then. The term food security has been defined in various ways. Maxwell and Frankenberger (1992) identified 13 groups of definitions of food security. Few of such definitions are reviewed hereafter; World Bank (1986) defined it as access by all people at all times to enough food for active and healthy life. Food security is also defined as the physical and economic access to adequate food for all household members without undue risk of loosing the access (FAO, 1989). A definition endorsed by the ICN (1992) states that food security is a state of affairs where all people at all times have access to safe and nutritious food to maintain a healthy and active life.

According to the Life Sciences Research Office (1990), food security implies the ready availability of nutritionally adequate and safe foods and an assured ability to acquire acceptable food in socially acceptable ways (for example without resorting to emergency food supplies, scavenging, stealing or other coping strategies). USAID (1992) gave a relevant statement which incorporates the fundamental concepts of various definitions of food security as when all people at all times have both physical and economic access to sufficient food to meet their dietary needs for a productive and healthy life.

In short, the main goal of food security is for individuals to be able to obtain adequate food needed at all times and to be able to utilize the food to meet the body's needs. Food security has been identified to have food availability, food accessibility, utilization and stability of food access as the elements (Bonnard, 1999; Kenedy, 2003, Obanuro et al., 2005; FAO 1996; Gross et al., 1999; Del Ninno et al., 2005). Food security indicates the availability of and access to food by those in need (Okumadewa et al., 1990). Mkandawire and
Matlosa (1993) defined it as the absence of hunger and malnutrition. Food security is distinguished from the three forms of hunger-transient, endemic and hidden. Endemic or chronic hunger is of a more permanent nature, caused by poverty and lack of access to balanced diets including both energy-rich and protein-rich foods, leading to protein-energy malnutrition. Productivity growth can play a major role in alleviating this insidious form of hunger.

Billions of people in developing countries also suffer from hidden hunger caused by a deficiency in micronutrients such as folate, iodine, iron, selenium and vitamins A and C. After Asia, Africa has the highest prevalence rate of hidden hunger with pregnant and lactating women and preschool children most at risk (FAO, 2002; CGIAR, 2002; Graham et al., 2001). In view of the foregoing, the study examined the determinants of food insecurity in Edo state, Nigeria. To achieve this objective the food insecurity line the effect of the socioeconomic characteristics of households on food insecurity and the probability of a household being food insecure were determined.

\section{MATERIALS AND METHODS}

Both primary and secondary data were used. The primary data were collected using a structured questionnaire. The stratified random sampling technique was used to collect the data. The target population for the survey was both rural and urban households from six communities whose occupational status is mainly farmers. The sampled households were selected from two adjoining Local Government Areas (LGAs) of Edo state, namely Oredo and Egor. From each local government area, 75 households of $25 \%$ from each community were randomly selected. A stratified random sample, totaling 150 households on the delineation of the LGAs of household heads was then selected. A questionnaire based on the social, economic, expenditure, income and consumption was used to collect data. About 150 copies of questionnaire were administered out of which 130 copies of completed questionnaire were retrieved representing a response rate of $87 \%$.

The secondary data, such as the nutritional equivalent of unit food item consumed by households and other recommended food bench-marks were sourced from Federal Office of Statistics, Central Bank of Nigeria, World Bank Report and Publication in Journals, Research Institute, Unversities and Government Parastatals. Data collected were subjected to both descriptive and inferential statistics such as the greer-thorbecke index of food insecurity and multivariate logit regression. A separate food insecurity line was defined for the area. To 
achieve this, a regression of the cost-of-calorie of food consumed by each household on the calorie equivalent as proposed by Foster et al. (1986) was used. This method has been applied to several studies whose main focus was on food insecurity (Hassan and Babu, 1991). Besides, the method satisfies the monotonicity axiom, focus axiom, symmetry axiom, transitivity axiom and additive and decomposability by population sub group. Therefore, following their approach, the food insecurity line was given as:

Where:

$$
\mathrm{E}=\mathrm{a}+\mathrm{bC}
$$

$\mathrm{E}=$ The adult equivalent food expenditure (in Naira)

$\mathrm{C}=$ The actual calorie consumption per adult equivalent of a household (in kilocal)

The calorie content of the recommended minimum daily nutrients level L (FAO, 1996; FBFI, 1995) was used to determine the food insecurity line, $\mathrm{Z}$ using the equation:

$$
Z=e^{a+b L}
$$

Where:

$\mathrm{Z}$ = The cost of buying the minimum calorie intake (food insecurity line), $a$ and $b$ are parameter estimates from the expenditure equation

$\mathrm{L}=$ The recommended minimum daily calorie level (The FAO recommended minimum daily energy requirement per adult equivalent is $2260 \mathrm{kcal}$ )

A household was then considered food secure or food insecure if the cost of calorie consumption was equal or above and below the food insecurity line, respectively. The degree of food insecurity was estimated using the equation shown as:

$$
P_{\alpha}=\frac{1}{n}\left(\sum_{i=i}^{n} G_{i}\right)=\frac{1}{n}\left(\sum_{i=i}^{n} \frac{Y_{i}-Z}{Z}\right)^{\alpha}
$$

Where :

$\mathrm{P}_{\alpha}=$ Degree of food insecurity for á taking values of 1 , 2 and 3 for headcount, short-fall and severity of food insecurity

$\mathrm{n}=$ The number of food insecure households

$\mathrm{G}_{\mathrm{i}}=$ The per capita calorie intake deficiency of the ith household

To assess the effect of socio-economic characteristics on food insecurity and the probability of a household being food insecure, data were collected on variables such as education, sex, output land cultivated, household size, per capita income of household head and other socio-economic variables. On the assumption that the probability of a household being food insecure is determined by an underlying response variable that capture the true economic status of a household, the underlying response variable $\mathrm{y}^{*}$ in the case of binary status was defined by the multivariate logit regression relation:

$$
\mathrm{y}_{\mathrm{i}}^{*}=\sum \mathrm{X}_{\mathrm{i}} \beta_{\mathrm{j}}+\mu_{\mathrm{i}}
$$

Where:

$\beta_{j}=\beta_{1}, \beta_{2}, \ldots, \beta_{j}$
$X_{i}=1, X_{i 2}, X_{i 3}, \ldots, X_{i k}$.

The relevant logistic expressions are given as:

$$
\operatorname{prob}\left(y^{*}=1\right)=1-F\left(\sum X_{i}^{\prime} \beta_{j}\right)=\frac{e^{\sum X_{i} \beta_{j}}}{1+e^{\sum X_{i}^{\prime} \beta_{j}}}
$$

and

$$
\operatorname{prob}\left(\mathrm{y}^{*}=0\right)=\mathrm{F}\left(-\sum \mathrm{X}_{\mathrm{i}}^{\prime} \beta_{\mathrm{j}}\right)=\frac{\mathrm{e}^{-\sum \mathrm{X}_{\mathrm{i}} \cdot \beta_{\mathrm{j}}}}{1+\mathrm{e}^{-\sum \mathrm{X}_{\mathrm{i}} \cdot \beta_{\mathrm{j}}}}=\frac{1}{1+\mathrm{e}^{\sum \mathrm{X}_{\mathrm{i}} \cdot \beta_{j}}}
$$

Where:

$\mathrm{F}=$ The cumulative distribution function for $\mu_{\mathrm{i}, \text { }}$

and

$$
\operatorname{prob}\left(\mathrm{Y}_{\mathrm{i}}=0 / \beta_{\mathrm{j}} \mathrm{x}_{\mathrm{i}}\right)=\mathrm{F}\left(-\sum \mathrm{x}_{\mathrm{i}}^{\prime} \beta_{\mathrm{j}}\right)
$$

$$
\operatorname{prob}\left(\mathrm{Y}_{\mathrm{i}}=0 / \beta_{\mathrm{j}} \mathrm{x}_{\mathrm{i}}\right)=1-\mathrm{F}\left(-\sum \mathrm{x}_{\mathrm{i}}^{\prime} \beta_{\mathrm{j}}\right)
$$

The likelihood function is given by:

$$
L=\prod_{y_{i}=0}\left[F\left(-\sum X_{i}^{\prime} \beta\right)\right] \prod_{y_{i}=1}\left[1-F\left(-\sum X_{i}^{\prime} \beta\right)\right]
$$

While the log likelihood function for the expression is:

$$
\begin{aligned}
& H(\beta)=\log L(\beta)=\sum_{i=0}^{n} y_{i} \log \\
& {\left[1-F\left(-\sum X_{i}^{\prime} \beta\right)+(1-y) \log F\left(-\sum X_{i}^{\prime} \beta\right)\right]}
\end{aligned}
$$

Where:

$\mu_{\mathrm{i},}=$ Follow a logistic cumulative distribution in $\mathrm{F}$

$\mathrm{X}_{\mathrm{i}}^{\prime}=$ Characteristics of households

$\beta_{\mathrm{j}}=$ The coefficients for the respective variables in the logit function

The probability of a household being poor and the corresponding change in probability due to unit change in a variable $\mathrm{X}_{\mathrm{i}}$ are given as:

$$
\operatorname{prob}\left(\mathrm{y}_{\mathrm{i}}=1 / \beta \mathrm{X}_{\mathrm{i}}=\frac{\mathrm{e}^{\varphi}}{1+\mathrm{e}^{\varphi}}\right.
$$


Agric.J., 5(3): 151-156, 2010

Table 1: Definition of variables used in the estimated equation

\begin{tabular}{|c|c|c|}
\hline Variables & Definitions & $\begin{array}{c}\text { Symbols } \\
\text { used }\end{array}$ \\
\hline Food insecurity (dependent) & $\begin{array}{l}\mathrm{P}=1 \text { if food insecure } \\
=0 \text { otherwise } \\
\text { (Food insecurity } \\
\text { estimatesbased on } \\
\text { cost of calorie } \\
\text { onsumption of } \\
\text { household) }\end{array}$ & $\mathrm{P}$ \\
\hline \multicolumn{3}{|l|}{ Explanatory variables } \\
\hline Sex of household head & $\begin{aligned} \mathrm{Sex} & =1 \text { if male } \\
& =0 \text { otherwise }\end{aligned}$ & $\mathrm{SHH}$ \\
\hline Education level of household head & $\begin{array}{l}=1 \text { if primary } \\
=0 \text { otherwise } \\
=1 \text { if secondary } \\
=0 \text { otherwise } \\
=1 \text { if tertiary } \\
=0 \text { otherwise }\end{array}$ & $\begin{array}{l}\text { EHHP } \\
\text { EHHS } \\
\text { EHHT }\end{array}$ \\
\hline Total holding of land cultivated (acres) & TLC & \\
\hline Output level of household (ton) & OLH & \\
\hline Age of household head (years) & $\mathrm{AHH}$ & \\
\hline Per capital income of household head (N) & $\mathrm{PCIH}$ & \\
\hline Household size & HHS & \\
\hline Household dependency ratio & HDR & \\
\hline
\end{tabular}

and

$$
\frac{\mathrm{d}\left[\mathrm{prob}\left(\mathrm{y}_{\mathrm{i}}=1 / \beta_{\mathrm{i}} \mathrm{X}_{\mathrm{i}}\right)\right]}{\mathrm{dX} \mathrm{X}_{\mathrm{i}}}=\beta_{\mathrm{i}}(1-\mathrm{p}) \mathrm{p}
$$

Where:

$\varphi=\sum_{\text {to a variable }} \beta_{\mathrm{j}} \mathrm{X}_{\mathrm{i}} \mathrm{P}$ is estimated value of the probability due
$\beta_{\mathrm{j}}=\quad$ Estimated $\mathrm{HDR}($ Table 1$)$

\section{RESULTS AND DISCUSSION}

Table 2 shows that calorie consumption equivalent can explain $75 \%$ of the food expenditure of households. The estimated regression line conforms to a priori expectation in sign and magnitude of the coefficients. With elasticity of $4.25 \times 10^{-4}$, it reveals that $0.0425 \%$ increase in the level of calorie consumption equivalent causes exactly $1 \%$ in the consumption expenditure level of household ceteris paribus. Also with $\operatorname{In} \mathrm{E}=4.43+$ $0.000425 \mathrm{C}$ and a recommended calorie intake of 2260 kilocal, the food insecurity line or cost of acquiring the Rrecommended Daily Allowance (RDA) of calorie was N218.79 k. This describes that it would require perfectly targeted transfer of $\mathrm{N} 218.79 \mathrm{k}$ per day per person to be food secure besides their per capita income. Table 3 shows that food insecurity was worse in the male headed household with food insecurity headcount index, shortfall index and severity of $75.62,5.62$ and $1.91 \%$, respectively than the female counterpart of $12.08,3.60$ and $1.21 \%$. This means that $75.62 \%$ of all the resources that would be needed to lift all the food insecure households out of food insecurity through perfectly targeted cash transfer will be used for male headed
Table 2: Estimated regression coefficients for expenditure on calorie consumption equivalent

\begin{tabular}{llllr}
\hline Coefficient & Estimate & Standard error & t-ratio & p-value \\
\hline Constant term (a) & $4.42762^{*}$ & 0.05003 & 8.51 & 0.000 \\
Elasticity (b) & $4.25 \times 10^{4 * *}$ & $2.269 \times 10^{5}$ & 19.62 & 0.000 \\
Standard error $=0.1738$ & $\mathrm{R}^{2}=75 \% *$ & $\mathrm{R}^{2}($ adj) $=73.5 \%$ & \\
\hline
\end{tabular}

Significant at $5 \%(\mathrm{p} \leq 0.05)$ level

Table 3: Estimated headcount, short-fall and severity of food insecurity by socio-economic characteristics of household

\begin{tabular}{|c|c|c|c|}
\hline Variables & Headcount index & Short-fall index & Severity \\
\hline \multicolumn{4}{|l|}{$\begin{array}{l}\text { Sex of household } \\
\text { head }\end{array}$} \\
\hline Male & 75.62 & 5.62 & 1.91 \\
\hline Female & 12.08 & 3.60 & 1.21 \\
\hline \multicolumn{4}{|l|}{$\begin{array}{l}\text { Education level } \\
\text { of hous ehold }\end{array}$} \\
\hline Primary & 37.92 & 8.80 & 2.98 \\
\hline Secondary & 0.57 & 0.44 & 0.20 \\
\hline Tertiary & 0.00 & 0.00 & 0.00 \\
\hline \multicolumn{4}{|l|}{$\begin{array}{l}\text { Output level } \\
\text { (tons) }\end{array}$} \\
\hline $1-5$ & 21.54 & 4.93 & 1.59 \\
\hline $6-10$ & 13.62 & 3.89 & 1.12 \\
\hline $11-15$ & 1.54 & 0.50 & 0.21 \\
\hline \multicolumn{4}{|l|}{ Household size } \\
\hline Small (1-5) & 14.65 & 3.27 & 0.95 \\
\hline Medium (6-10) & 24.08 & 6.09 & 2.05 \\
\hline Large (above 10) & 0.00 & 0.00 & 0.00 \\
\hline \multicolumn{4}{|l|}{ Age (years) } \\
\hline $21-30$ & 1.58 & 0.40 & 0.24 \\
\hline $31-40$ & 10.70 & 2.57 & 0.87 \\
\hline $41-50$ & 13.10 & 2.90 & 0.86 \\
\hline $51-60$ & 6.15 & 1.56 & 0.58 \\
\hline Above 60 & 6.13 & 1.98 & 0.77 \\
\hline
\end{tabular}

households, $5.62 \%$ means that the cash transfer needed to lift the food insecure households out of food insecurity, each food insecure person represents $5.62 \%$ of the food insecurity line while the $1.91 \%$ represents the inequality among the food insecure household. The results indicated that male headed households were more food insecure than female headed households. The distribution was not unexpected since most women are more adept than men in issues involving expenditure and calorie. Food insecurity was concentrated in the group with primary education having an estimated headcount index, short-fall index and severity of $37.92,8.80$ and $2.98 \%$, respectively but no food insecurity level of any index was recorded for those with tertiary education. Thus calorie consumption improved as the level of education of household head improved.

High indices of food insecurity was recorded for low output farmers than high output farmers. This implies that as the output level of the households increased, their calorie consumption improved. Food insecurity was more severe in the medium size household with food insecurity, headcount index, short-fall index and severity as 24.08 , 6.09 and $2.052 \%$, respectively. This does not mean that 
Agric. J., 5(3): 151-156, 2010

Table 4: Binomial logit estimate for the determinants of food insecurity and the probabilities of a household being food insecured Coefficients Marginal

\begin{tabular}{lcccc} 
Variables & Estimated $\beta$ values & Z-values & $\operatorname{Prob}(\mathrm{Y}=1)$ & effect $(\mathrm{dp} / \mathrm{dx})$ \\
\hline $\mathrm{SHH}^{*}$ & -0.129 & -0.098 & 0.476 & $-0.032^{*}$
\end{tabular}

$\mathrm{EHH}--$

Primary*

Secondary ${ }^{*}$

Tertiary $^{*}$

HHS

OLH

HDR

AGE

PCIHH

TLC

Constant

Count $\mathrm{R}^{2}=0.81, \mathrm{R}_{\text {MCF }}^{2}=0.34 .{ }^{*} \mathrm{dy} / \mathrm{dx}$ is for discrete change of dummy variable, $* *$ significant at $5 \%$ level, ${ }^{* * *}$ significant at $1 \%$ level

food insecurity worsened as household size increased since the large size household had no food insecurity index (zero food insecurity status). Food insecurity was high for age group 41-50 years with food insecurity headcount index, short-fall index and severity of $13.10 \%$. Table 4 shows that only House Hold Size (HHS), age of household head and Household Dependency Ratio (HDR) are positively related to the probability of a household being food insecure while other variables are negative related. This implies that household size, age and household dependency ratio worsen food insecurity (reduce the per capita calorie intake of a household) as the household size, age and household dependency ratio increase while the others reduce the probability of a household being food insecure as their values increase. The logit value of the household size was 1.878 with a partial coefficient of 0.312 .

This means that ceteris paribus, if household size increases by a unit, on average, the estimated logit increases by 0.312 . Household size adds 0.036 to the probability of a household being food insecure for every unit change in household size. Also the probability of a household being food insecure, consequent on household size was 0.867 . The logit value for household dependency ratio was 1.481 and a marginal value of 0.005 and its impart on the probability of being food insecure was 0.815 .

The education (secondary and tertiary) of household reduces the probability $(-0.322$ and -0.286 for secondary and tertiary) than any other determinants of food insecurity. Also education is the most significant determinant of food insecurity with the probability of being food insecure due to primary, secondary and tertiary education of $0.463,0.311$ and 0.128 , respectively. There is no exception to this since all levels of education are significant. Thus an improvement in the education status of a household reduces the food insecurity status. The absolute marginal effect of per capita income of household is least (0.00006) among the determinants of food insecurity but the highest absolute logit value (1.660) and a probability of a household being food insecure as 0.16 . At the mean values of variables as given in the Table 4 , the probability of a household being food insecure was 0.997 (99.7\%).

For example household with a male head with primary education, land cultivated of 2.98 acres, output level of 1460 ton, 42 year of age, per capita income N3980 and a household size of 6 has a probability of 0.04 (4\%) of being food insecure. Given the same condition but with a tertiary education has a probability of $0.007(0.7 \%)$.

Policy implication: A number of specific policy implications can be drawn from the result. The following policy implications of the study stand out. The educational attainment of the head of the household was found to be the most significant determinant of food insecurity. The low level of education accounts for a higher probability of any household being food insecure. The promotion of education is, therefore of paramount importance in addressing the problems of food insecurity. The House Hold Size (HHS) was another determinant of food insecurity in the study area. Household heads are advised to reduce the size of their household and their dependency ratio. Education will again play a role in reducing the household size. A high level of education will help to maintain a decent household size. The per capita income of household head also affect food insecurity with coefficient of regression of -0.000417 resulting in a probability of being food insecure of 0.16 $(16 \%)$ at a mean per capita income of household head of N3980. At this per capita income, a household has a low odd ratio of 0.19 (ratio 2-10). Other thing being equal, the PCIHH of these households will have to be increased to raise the value of the odd ratio. One way to achieve this is by improving on the income-earning capability of the farmers.

\section{CONCLUSION}

In this study, an attempt has been made to explore the determinant of food insecurity in Edo state, Nigeria. The study employed the Greer-Thorbecke food insecurity index to assess headcount index, short-fall index and severity of food insecurity and a binomial logit model to assess the determinants of food insecurity. The education level of farmers, household size, output level of household and per capita income of the household are the major determinants of food insecurity in the area while the 
probability of a household being food insecure is due to household size, household dependency ratio, sex of household head, age and the level of education of the household head.

\section{REFERENCES}

Abulu, G.O.I., 1990. The attainment of food security in Nigeria: The role of resources constrained Nigeria farmers. Keynote Address: Nigerian National Farming Systems Research Network.

Ayalew, M., 1997. What is food security and famine and hunger. Int. J. Afr. Stud.,

Bonnard, P., 1999. Increasing the Nutritional Impact of Agricultural Interventions. FANTA, Washington, DC., pp: 20.

CGIAR, 2002. Biofortified Crops for Human Nutrition: A CGIAR Challenge Program Proposal Draft. Consultative Group on International Agricultural Research, Washington, DC.

Del Ninno, C., P.A. Dorosh and K. Subbarao, 2005. Food aid and food security in short and long-run: Country experiences from asia and sub-sahara Africa. World Bank, pp: 1-122, http://siteresources. worldbank.org/ SAFETYNETSA NDTRANSFERS/ Resources/281945-1131468287118/1876750-1140729 565108/delNinno-FoodSecurity_PPT.pdf.

FAO, 1989. Preparation of Comprehensive National Food Security Programme: Overall Approaches and Issues. Food and Agriculture Organization, Rome.

FAO, 1996. The Rome declaration on world food security. Popul. Dev. Rev., 22: 807-809.

FAO, 2002. Food Insecurity: When People Must Live with Hunger and Fear Starvation. Food and Agriculture Organization, Rome, Italy, pp: 36.

FAO, 2005. The State of Food Insecurity 2004. International Food Policy Research Institute, FAO, Rome, pp: 1-33.

FBFI, 1995. Nutrient Composition of Commonly Eaten Foods in Nigeria-Raw, Processed and Prepared. Food Basket Foundation Publication, Ibadan, pp: 131.

Foster, J., J. Greer and E. Thorbecke, 1986. A methodology for measuring poverty applied to Kenya. J. Dev. Econ., 24: 59-74.

Graham, R.D., R. Welch and H. Bouis, 2001. Addressing micronutrient malnutrition through enhancing the nutritional quality of staple foods: Principles, perspectives and knowledge gaps. Adv. Agron., 70: $77-142$.
Gross, R., W. Schultrink and A.A. Kielman, 1999. Community Nutrition: Definition and Approachers. In: Encyclopedia of Human Nutrition, Saldler, M., J.J. Strain and B. Caballero (Eds.). Academy Press Limited, London, pp: 433-441.

Hassan, R.M. and S.C. Babu, 1991. Measurement and determinants of rural poverty: Household consumption patterns and food poverty in rural Sudan. Food Policy, 16: 451-460.

ICN, 1992. Plan of Action. FAO and WHO, Rome, Italy.

Idachaba, F.S., 2004. Food security in Nigeria: Challenges under democratic dispensation. Proceeding of the 9th Agricultural and Rural Management Training Institute (ARMTI) Annual Lecture, March 24, Ilorin, pp: 1-23.

Kenedy, G., 2003. Food security in the context of urban sub-sahara Africa. Food Africa Internet Forum, http://foodafrica.nri.org/urbanisation/urbspapers/ GinaKennedyFoodsecurity.pdf.

Life Sciences Research Office, 1990. Federation of American Societies For Experimental Biology. In: Core Indicators of Nutritional State for Difficult-toSample Populations, Anderson, S.A. (Ed.). American Institute of Nutrition, USA., pp: a-1.

Maxwell, S. and T. Frankenberger, 1992. Household Food Security Concepts, Indicators and Measurements. IFAD and UNICEF, Rome.

Mkandawire, R. and K. Matlosa, 1993. Post-Colonial State and food security in Southern Africa: An Overview in food Policy and Agriculture in Southern Africa. Atlantic Philosophy of Education Society, Southern Africa, pp: 3-7.

Obanuro, E.O., W. Doppler and P. Kormwa, 2005. Pillars of food security in rural areas of south-west Nigeria. Food Africa, Internet Forum, 31st March-11 th April.

Okolo, D.A., 2004. Regional study on agricultural support: Nigeria case. Special Study Report Prepared for the Food and Agriculture Organization, pp: 1-97, http://www.fao.org/tc/tca/work05/Nigeria.pdf.

Okumadewa, F., A. Olomola and B. Adubi, 1990. Trade Liberalization and Food Security: Situation Analysis in Nigeria. Development Policy Centre, Ibadan, Nigeria.

Olayemi, J.K., 1998. Food Security in Nigeria. Research Report Prepared for the Development Policy Centre, Ibadan, Nigeria pp: 1-86.

Rasaki, A.S., A.B. Catherine and O.Y. Bidemi, 2006. Measuring household food insecurity in selected local government areas of lagos and Ibadan, Nigeria. Pak. J. Nutr., 5: 62-67.

USAID, 1992. Policy Determination: Determination of Food Security. USAID, Washington, DC.

World Bank, 1986. Poverty and Hunger: Issues and Options for Food Security in Developing Countries. The World Bank, Washington DC. 